\title{
ВПРОВАДЖЕННЯ ВІРТУАЛЬНИХ МОДЕЛЕЙ У НАВЧАЛЬНИЙ ПРОЦЕС ВИВЧЕННЯ ФІЗІОЛОГІї
}

\begin{abstract}
ДВНЗ «Івано-Франківський національний медичний університет»
У статті розкрито необхідність модернізації навчального процесу вивчення фізіології шляхом впровадження інноваційних методів навчання, зокрема віртуального моделювання. Вказана методика може покращити якість вивчення дисципліни та набагато точніше відобразити процеси життєдіяльності в людському організмі.
\end{abstract}

ключові слова: віртуальні моделі, фізіологічні функції, інноваційні технології.

\section{ВНЕДРЕНИЕ ВИРТУАЛЬНЫХ МОДЕЛЕЙ В УЧЕБНЫЙ ПРОЦЕСС ИЗУЧЕНИЯ ФИЗИОЛОГИИ}

Т. В. Гуранич

ГВУЗ «Ивано-Франковский национальный медицинский университет»

\footnotetext{
В статье раскрыта необходимость модернизации учебного процесса изучения физиологии путем внедрения инновационных методов обучения, в частности виртуального моделирования. Данная методика может улучшить качество изучения дисциплины и более точно отразить процессы жизнедеятельности в человеческом организме.

ключевые слова: виртуальные модели, физиологические функции, инновационные технологии.
}

\section{THE INTRODUCTION OF VIRTUAL MODELS IN THE LEARNING PROCESS OF PHYSIOLOGY STUDYING}

\section{T. V. Huranych}

\section{SHEI «Ivano-Frankivsk National Medical University»}

\begin{abstract}
The necessity to modernize the educational process of physiology studying by the introduction of innovative teaching methods, in particular virtual modeling is considered in the article. Such method can improve the quality of the discipline studying and more accurately reflect the vital processes in the human body.
\end{abstract}

Key words: virtual models, physiological functions, innovative technology.

Вступ. Фізіологія є однією із найважливіших фундаментальних дисциплін у системі медичної освіти, тому повинна забезпечити формування у

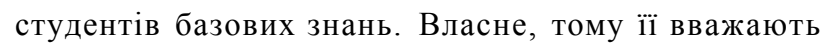
теоретичною основою медицини. Фізіологія людини - це наука про життєдіяльність організму, його окремих систем, органів і тканин, регуляцію фізіологічних функцій, закономірності взаємодії живих організмів із довкіллям, їх поведінку в різних умовах існування. Без глибокого знання законів функціонування клітини, значення нормальних змін їі молекулярної будови, процесів життєдіяльності тканин і органів, взаємодії людського організму 3 зовнішнім середовищем неможливе розкриття (c) Т. В. Гуранич закономірностей порушення функцій, запобігання захворюванням та їх лікування. Глибоке вивчення механізмів фізіологічних функцій - необхідна умова подовження якості та тривалості життя людини, раціональної організації оздоровчих заходів, розробки нових методів профілактики та лікування захворювань [1]. Знання дисципліни широко застосовуються у всіх сферах життєдіяльності. Фізіологію людини вважають основою соціальної та особистої гігієни, охорони материнства та дитинства, шкільної гігієни, раціональної організації праці. Фізіологія харчування дає практичні знання щодо основ збалансованого та раціонального харчування. Кліматична фізіологія рекомендує 


\section{МЕДИЧНА ІНФОРМАТИКА TA IHЖЕНЕРІЯ}

дозування природних факторів зовнішнього середовища. Авіаційна та космічна фізіологія науково обгрунтовує умови збереження здоров'я людей під час польотів та в космосі. Виховання фізично здорового молодого покоління, трудові аспекти та заохочення всіх видів спорту й фізичної культури засновані на практичному використанні вікової фізіології та фізіології спорту.

Основна частина. Сучасний рівень освітніх послуг невпинно зростає та вимагає від вітчизняної системи медичної освіти постійно йти в ногу 3 часом, бути тісно пов'язаними 3 євроінтеграційними напрямками держави задля представлення конкурентоспроможних фахівців на світовому ринку праці. В умовах глобалізації назріла нагальна необхідність модернізації системи освіти, активізації навчальної діяльності студентів, що реалізується через упровадження різноманітних інноваційних форм і методів навчання, новітніх підходів до викладання навчальних дисциплін, зокрема фізіології.

3 цієї точки зору одним із найефективніших методів є віртуальне моделювання [2]. В освітній діяльності студентів при використанні поняття «віртуальність» йдеться про впровадження мультимедійних, телекомунікаційних та інших електронних засобів і технологій навчання. Ефективність навчально-пізнавальної діяльності, рівень підготовки студентів-медиків, зокрема із фізіології, значно підвищуються за умов активного впровадження інноваційних технологій навчання, однак досвід розробок і використання предметних віртуальних програм у навчальному процесі медичних вузів практично відсутній [3].

Моделювання біологічних систем належить до активних методів навчання. Це спонукає всіх суб'єктів навчального процесу до пошуку, часто вимагає різноманітних практичних дій. Основні функції моделювання в цьому випадку зводяться до описової, імітаційної, аналітичної, творчої. Віртуальна модель служить джерелом інформації на початковому етапі вивчення матеріалу, як об'єкт пізнання, як носій навчальної інформації, як засіб створення проблемної ситуації, матеріал для аналізу типових явищ тощо [4].

Для поглибленого розуміння кількісних та якісних закономірностей фізіології людини вже

\section{Література}

1. Ліссов П. М. Технологія створення програмного комплексу для моделювання фізіологічних систем / багато років розробляються віртуальні моделі різноманітних фізіологічних функцій. Для імітаційних досліджень фізіології на сучасному рівні необхідно розробляти комплексні моделі, які описують взаємозв'язок різних систем. Вони мають відображати закономірності функціонування на субклітинному, клітинному, органному, системному рівнях організації [5]. Виникає завдання створення спеціалізованих програмних засобів, що забезпечують весь цикл проведення комп'ютерних імітаційних досліджень шляхом компонування моделей, налаштування їх та аналізу результатів імітаційних експериментів. У той же час, створити цілісну модель організму людини доволі складно. 3 практичної точки зору доцільною $є$ розробка віртуальних моделей окремих функціональних систем та алгоритми їх наступної взаємодії [6, 7]. Зокрема, при вивченні розділу «Фізіологія збудливих тканин» доречним $\epsilon$ створення моделей генерації потенціалу дії, поширення нервового імпульсу по нервових волокнах, скорочення поперечносмугастих і гладких м'язів. У розділі «Фізіологія центральної нервової системи» варто демонструвати студентам віртуальні моделі рефлекторної діяльності центральної нервової системи на різних рівнях спинного та головного мозку. Під час вивчення гуморальної регуляції організму можна запропонувати моделі різноманітних ендокринних захворювань, на основі яких студентам буде легше та цікавіше зрозуміти фізіологічну роль різноманітних гуморальних чинників. У розділі «Фізіологія вісцеральних систем» доречним $\epsilon$ моделювання внутрішніх органів і систем органів, на основі яких можна вивчати їх фізіологічну роль та функції у цілісному організмі. Під час розгляду розділу «Фізіологія сенсорних систем» віртуальні моделі аналізаторів допоможуть більш наочнно $\mathrm{i}$ точно зрозуміти функції органів чуття та механізми їх можливих розладів.

Висновок. Використання віртуальних моделей перебігу різноманітних фізіологічних функцій під час проведення практичних занять із фізіології може сприяти досконалому оволодінню студентами базових знань із даної дисципліни та дозволяє наочно осмислити генез процесів життєдіяльності в людському організмі.

П. М. Ліссов // Проблеми програмування. - 2008. № 2-3. - С. 770-776. 
2. Григорян Р. Д. Программно-моделирующий комплекс для теоретических исследований взаимодействия физиологических систем человека / Р. Д. Григорян, П. М. Лиссов // Проблеми програмування. - 2006. № 1. - С. 79-92.

3. Шершун Г. Г. Досвід розробки і впровадження віртуальних програм 3 біохімії в навчальний процес / Г. Г. Шершун, М. М. Корда // Медична освіта. - 2014. - № 3. - С. 155-156.

4. Коцюба Р. Б. Використання віртуальних навчальних програм при вивченні іноземної мови професійного спрямування / Р. Б. Коцюба // Інформаційні технології і засоби навчання. - 2013. - Т. 37, № 5. - С. 43-52.
5. Анчева І. А. Роль віртуальних технологій в якості професійної підготовки медичних працівників / І. А. Анчева // Медична освіта. - 2014. - № 3. - С. 10-12.

6. Кравець Н. Я. Застосування методу моделювання в процесі навчання мікробіології / Н. Я. Кравець, І. М. Грод, Л. О. Шевчик // Медична освіта. - 2014. № 1. - С. 44-47.

7. Simulation-based objective assessment discerns clinical proficiency in central line placement a construct validation / Y. Dong, H. S. Suri, D. A. Cook [et al. ] // Chest. - 2010. - Vol. 137 (5), № 6. - P. 1050-1056. 